\title{
Research on Pattern of Law Education in Big Data Era from the Perspective of MOOC
}

\author{
Liya Luo ${ }^{1,2}$ \\ China University of Political Science and Law ${ }^{1}$ \\ Beijing, China 100088 \\ School of Marxism \\ Guizhou University of Finance and Economics ${ }^{2}$ \\ Guiyang, China 550025
}

\begin{abstract}
Rapid development of big data especially network information greatly impacts the traditional pattern of law education and has far-reaching influence on it. It is new attempt to explore "how to teach" in law education through paying attention to the influence brought by big data technology and building pattern of law education. Under the background of big data era, from the perspective of application of MOOC in teaching, patterns of law education are explored to provide more diversified and personalized selections for it.
\end{abstract}

Keywords — big data era; MOOC; pattern of law education

\section{INTRODUCTION}

The rapid development of big data especially network information greatly impacts the traditional pattern of law education and has far-reaching influence on it. At present, educators in universities have paid attentions to the pattern of law education in big data era. Emerging educational patterns such as MOOC along with IT revolution provide more alternatives for "how to teach" in law education. Relations and influences of big data and patterns of law education at present are discussed, in order to explore patterns of law education and train high quality law talents.

\section{CONCEPT AND CHARACTERISTICS OF BIG DATA AND MOOC}

\section{A. Concept and Characteristics of Big Data}

In recent years, big data become new development trend and new resource in information era. With soaring development and huge opportunities and value, it will greatly influence revolution and development in many fields. Attentions are paid to big data. On March 29, 2012, to address the conclusion of federal government that "investment in big data technology is insufficient", President of the United States Obama at that time announced Initiative on Big Data Research and Development, in order to improve the ability to acquire knowledge through complicated data and improve insight ability. The investment reaches up to 200 million US dollars for construction of latest technology in collecting and managing big data. 1 Taking it as an opportunity, in academic world and industrial circle, big data comes onto the historical stage.

Big data has no unanimous definition. The pioneer in big data research, International Data Center (IDC) defined it in the report in 2011 as, "Big data technology depicts new era of technology and system and extracts the value of largescale diversified data through high-speed capture, discovery and analysis technology". The definition depicts four marked features of big data, namely large data volume, diversified data type, fast speed of data processing and low density of data value. 2 It is widely-used in most researches.

\section{B. Concept and Characteristics of MOOC}

MOOC refers to "Massive Open Online Courses" and dates back to 1962. In 2008, it was proposed by Dave Cormier and Bryan Alexander in Canada. In 2012 called "the first year of MOOC", American top universities like Harvard University and Stanford University established network learning platforms to provide free online courses. MOOC pattern including three online education platforms namely Coursera, Udacity and edX establishes and develops rapidly. In 2013, some renowned universities in China such as Peking University and Tsinghua University joined in edX, Fudan University and Shanghai Jiaotong University joined in Coursera platform. So far, the development of MOOC is soaring under the help of forces that promote the information-based development of education. It sweeps across the globe and influences people's work, learning and life, especially students' thoughts and behaviors. Therefore, educators must open up thinking, innovate in idea and conform to the historical trend of the time, in order to realize individualized training of college students through application of MOOC.

MOOC has the following characteristics: large information capacity, fast propagation speed, wide influence scope and various communication modes. Internet IT revolution brought by big data and the popularization of internet as well as the application of internet terminals make transmission modes of MOOC personalized, alternative, flexible and elaborative and realize information synchronization of educator and educatee. 


\section{Relationship between Big Data and MOOC Development}

The development of big data depends on large-scale data, but big data is not formed by mass data. The value of big data is the analysis and application of complex data. To apply big data to educational field, we must transform it into information and present it in front of the audiences through carriers that contain a large mount of information and rapidly transform and transmit resources. MOOC becomes the medium of big data and educational field and embodies the function of big data in educational field.

\section{INFLUENCE OF BIG DATA ERA ON PATTERNS OF LAW EDUCATION IN UNIVERSITIES-FROM THE PERSPECTIVE OF MOOC}

Just as the description in Big Data Era, "Data resembles a magical diamond mine, the first value of which can give continuously after being excavated". 3 Big data era impacts education system and brings opportunities and challenges for law education. In January 2017, the 39th Statistical Report on Internet Development of China (hereinafter referred to as Report) issued by CNNIC indicates, by December 2016, the number of cyber citizens in China reaches 731 million and the internet penetration rate reaches 53.2 percent, exceeding 3.1 percent of global average and 7.6 percent of average in Asia. 4 The progress of mobile internet technology and the establishment of digital learning platform influence people's daily life. Network changes our learning style. Knowledge diffusion and information acquisition break the limitation of time and space and realize informatization of law education.

\section{A. Big Data Era Provides Diversified Choices for Patterns of Law Education in Universities}

In big data era, under the help of network information technology, MOOC gathers high quality teachers and affluent course resources and breaks the limitation of time and space in traditional class to meet students' requirements in using "fragmented time" to learn. Big data provides lively and interesting teaching cases for MOOC, which is spread through intelligent terminals to help students understand concepts or theories. Students learn repeatedly after class, in order to firmly grasp basic knowledge of law and improve learning effectiveness.

\section{B. Big Data Era Realizes Blended Learning of Law Education in Universities}

Horizon Report of New Media Consortium: 2017 Higher Education Version (hereinafter referred to as Horizon Report) completed by NMC and ELI is released officially in February 2017. It elaborates contents of 18 themes that most likely influence technology planning and decision making in the future five years (2017-2020).

Just as the description in Horizon Report, "In the past few years, people have changed attitudes toward online learning which is popular among more students and teachers. They regard it as a feasible alternative of face-to-face learning. Blended learning is the best practical experience that integrates online learning with face-to-face learning", 5 Blended learning is proposed in Horizon Report for five years in a row, obviously, it is important in future learning pattern.

Depending on information-based development of education promoted by big data, flexibility and convenience of blended learning are acknowledged by higher education. Blended learning is increasingly used in law education in universities. The discipline of law science is theoretical and practical. Restricted by time, space and other factors, teachers can only teach theories in class and students practice after class without effective feedback. The traditional educational pattern makes students trained by law education separate from the society. The teacher fails to know whether students effectively apply theories to practice. Meanwhile, students have difficulties in grasp useful vocational skills.

The coming of big data era and the change of teaching methods realize practice in class through blended learning. Big data can be used to analyze students' problems in practice. Teachers know students' application of theoretical knowledge of law and knowledge points in which they are interested. They can adjust teaching according to big data analysis and help students effectively apply theoretical knowledge to practice.

\section{Big Data Era Avails Individualized Learning in Law Education of Universities}

In April 2015, the Ministry of Education introduced Opinions on Construction, Application and Management of Online Open Courses in Universities to promote benign development of large-scale online open course of "university orientation, government support and social participation": "Chinese University MOOC" of "iCourse", "xuetangx.com" of Tsinghua University and "CNMOOC" of Shanghai Jiaotong University and large-scale online open courses developed by universities and internet enterprises appear to freely develop Chinese top-level courses of higher education and drive sustainable growth of user scale in online education. ${ }^{6}$ According to requirements of the Ministry of Education, provinces and cities construct MOOC, indicating the combination of law education and MOOC breaks the limitation of space and time. In other words, the combination of law education and MOOC strengthens students' experience of independent study and realizes individualized law education.

\section{CONSTRUCTION OF PATTERN OF LAW EDUCATION IN BIG DATA ERA}

With rapid development of new information technology, people enter big data era with large volume of data, varied types, fast changes and big potential value. The revolution of network information technology has far-reaching influence on law education in universities. At present, patterns and courses of law education fail to meet social demands. The reform of law education is imperative. Thoughts and ideas, teaching patterns, educational technology and responsibilities of educators should be 
changed accordingly. ${ }^{7}$ Teaching contents, teaching ideas and teachers are three teaching resources, through which the construction of pattern of law education in big data era is explored.

\section{A. Establish Teaching Resource Database of Law Education in Universities}

Teaching contents are important teaching resource, on which advanced teaching ideas and high quality teachers must depend on. At present, most successful databases of law education at home and abroad are research-based databases that are used by judicial departments like court and procuratorate, legal person institutions like enterprises and law office, law educators, researchers and learners. 8 Teaching resource databases related to law education haven't been established. Therefore, according to characteristics of big data like large volume of data and varied data type, we can conclude, analyze and extract data information that meets demands of law education through measurement, collection and analysis of related data in students' theoretical learning and practice, in order to provide data support for the establishment of teaching resource database of law education.

\section{B. Update Teaching Idea of Law Education in Universities}

Big data era depends on mass data and realizes analysis, utilization and innovation of it. Extensive application of big data impacts and influences economic development and social operation as well as traditional patterns of law education. In order to train information-based talents of law, in law education, attentions must be paid to theoretical teaching in class, especially the cultivation of students' ability in analysis of legal practice. Meanwhile, teachers timely adjust teaching contents and methods through big data analysis to realize precise law education. Conforming to development tendency of big data era and updating ideas of law education in universities broadens the horizon and provides effective support for training of law talents.

\section{Improve Teachers' Ability in Applicaton of Digital Learning Platforms}

Educational transformation and development is demand of the times. The popularization and application of digital learning platforms raises higher requirements for teachers' data literacy. It changes teachers' role in traditional teaching pattern that is transformed into teaching interaction of "teach students in accordance with their aptitude". Therefore, teachers' ability in using digital learning platforms will influence the actual effects of digital teaching pattern on reform of law education. Skilled application of educational information technology makes online courses attractive, offline teaching developmental and strengthens the interaction between teachers and students, in order to promote the reform of law education through big data.

\section{CONCLUSION}

In the big data era, patterns of law education in universities face challenges and unprecedented opportunities.
The development of network information technology takes education to digital era. Because of conforming to innovation consciousness required by the reform of educational patterns, big data becomes remarkable research object. The innovation of educational informatization inevitably aims at the reform of educational patterns primarily. The coming of big data era promotes the revolution of patterns of law education. Although we cannot instantly depict the outline after revolution, the far-reaching influence of big data on patterns of law education can be foreseen through exploration of relations between them and the organic combination.

\section{REFERENCES}

[1] Liu Dabei, Jia Yiwei: Initiative of Japan on Talent Training in Big Data Era: Formulation Background, Research Direction, Plan and Measures [J], E-government, the 10th Issue in 2015

[2] Zhang Jiyu: Main Challenges and Opportunities Faced by Chinese Judiciary in Big Data Era: Requirements of Judiciary for Law Research and Talent Training in Big Data Era [J], Law and Social Development, the 6th Issue in 2016

[3] Viktor Mayer-Schonberger, Kenneth Cukier, Big Data Era [M], translated by Zhou Tao. Hangzhou: Zhejiang People's Publishing House, 2013: 36

[4] Statistical Report on Internet Development of China [R], China Internet Network Information Center, Jan.22, 2017

[5] Adams Becker, S. 、 Cummins, M. Davis, A.\& Freeman, A.\& Hall Giesinger, C. \& Ananthanarayan, V. translated by Yin Bingshan, Gao Qian, Ren Zhi and Liu Xinchi: Horizon Report of New Media Consortium: 2017 Higher Education Version [R], Journal of Open Learning, the 2nd Issue in 2017

[6] Opinions on Construction, Application and Management of Online Open Courses in Universities [Z], the Ministry of Education of the People's Republic of China, Apr.28, 2015

[7] Wang Xin: Predicament and Reform of Law Education in Big Data Era [J], Research on Higher Education of Finance and Economics, the 19th Volume, the 4th Issue in 2016

[8] Chen Bing, Cheng Qian: Outline of Database Design in Law Practice Teaching in Universities in Big Data Era [J], the 48th Volume, the 1st Issue in 2015 